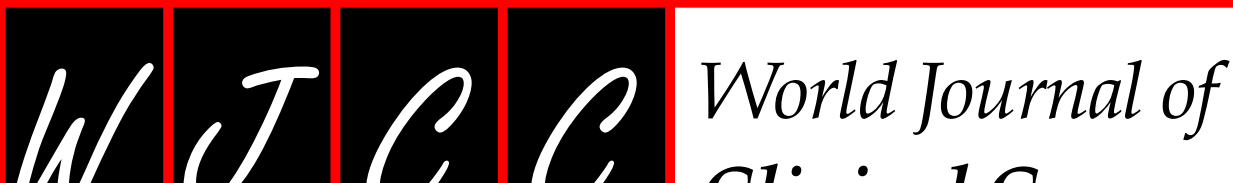 \\ Clinical Cases
}

Submit a Manuscript: http:/ / www.wjgnet.com/esps/

Help Desk: http:/ /www.wjgnet.com/esps/helpdesk.aspx

DOI:10.12998/wjcc.v2.i5.120

World J Clin Cases 2014 May 16; 2(5): 120-125

ISSN 2307-8960 (online)

(C) 2014 Baishideng Publishing Group Inc. All rights reserved.

\section{Nutritional deficiencies in the pediatric age group in a multicultural developed country, Israel}

\author{
Motti Haimi, Aaron Lerner
}

Motti Haimi, Children's Health Center, Clalit Health Services, Bruce and Ruth Rappaport School of Medicine, Technion-Israel Institute of Technology, 34369 Haifa, Israel

Aaron Lerner, Pediatric Gastroenterology and Nutrition Unit, Carmel Medical Center, Bruce and Ruth Rappaport School of Medicine, Technion- Israel Institute of Technology, 34369 Haifa, Israel

Author contributions: Lerner A designed the research; Haimi $\mathrm{M}$ performed the computer search; Haimi M and Lerner A wrote the paper; both authors contributed equally to the work. Correspondence to: Dr. Motti Haimi, MD, Senior Pediatrician, Children's Health Center, Clalit Health Services, Bruce and Ruth Rappaport School of Medicine, Technion-Israel Institute of Technology, Armon Tower, Neveim 18, 34369 Haifa,

Israel.mottiha@clalit.org.il

Telephone: +972-4-8351644 Fax: +972-4-8351650

Received: November 12, 2013 Revised: January 15, 2014

Accepted: March 17, 2014

Published online: May 16, 2014

\section{Abstract}

Nutrient deficiencies are prevalent worldwide. Diseases and morbid conditions have been described to result from nutritional deficiencies. It is essential to address nutrient deficiencies as these may lead to chronic longterm health problems such as rickets, iron deficiency anemia, goiter, obesity, coronary heart disease, type 2 diabetes, stroke, cancer and osteoporosis. In the present review we surveyed the extent and severity of nutritional deficiencies in Israel through a selective and comprehensive Medline review of previous reports and studies performed during the last 40 years. Israeli populations have multiple nutritional deficiencies, including iron, calcium, zinc, folic acid, and vitamins B12, C, D and E, spanning all age groups, several minorities, and specific regions. In Israel, some of the nutrients are mandatorily implemented and many of them are implemented voluntarily by local industries. We suggest ways to prevent and treat the nutritional deficiencies, as a step to promote food fortification in Israel.
(C) 2014 Baishideng Publishing Group Inc. All rights reserved.

Key words: Nutrient deficiencies; Type 2 diabetes; Obesity; Israel

Core tip: In view of the wide nutritional deficiencies in Israel, we encourage local health, education and industrial ministries to expand efforts to study and document those deficiencies with the vision of fortifying basic commonly used foods in order to fight the deficiencies and prevent their occurrence in the future.

Haimi M, Lerner A. Nutritional deficiencies in the pediatric age group in a multicultural developed country, Israel. World J Clin Cases 2014; 2(5): 120-125 Available from: URL: http://www. wjgnet.com/2307-8960/full/v2/i5/120.htm DOI: http://dx.doi. org/10.12998/wjcc.v2.i5.120

\section{INTRODUCTION}

Despite some reductions in world income-related poverty in recent years, malnutrition remains widespread. Nutrient deficiencies of iron, vitamin A, folic acid and zinc are prevalent worldwide, especially in children from low income areas ${ }^{[1]}$.

The lack of sufficient amounts of micronutrients affects health, function, and physical and cognitive development throughout the life cycle ${ }^{[1-4]}$. Many diseases and morbid conditions have been described to result from nutritional deficiencies. These include developmental defects, such as birth defects, physical and cognitive development delays, increased risk of infectious diseases, as well as increased risk of poor health in adulthood. Almost two-thirds of deaths of young children around the world are related to nutritional deficiencies ${ }^{[5-7]}$.

The discovery of essential nutrients and their roles in disease prevention has been instrumental in reducing 
nutritional deficiency diseases such as goiter, rickets, pellagra and others in many places such as the United States, Canada, European countries and third world regions. In Israel, a state of massive immigration, where a substantial part of the population lives below the poverty line, there is a relatively high percentage of unemployment, and also aging of the population. These aspects contribute to the relatively high prevalence of essential nutrient deficiencies in various parts of the Israeli population, including iron-deficiency anemia, goiter and vitamin D deficien$\mathrm{cy}^{[8-11]}$. Low vitamin B12 levels, low folic acid levels and consequently high homocysteine levels, and increased risk of coronary heart disease have also been observed in the Israeli population ${ }^{[12,13]}$. The regulatory authorities in Israel have been planning to implement food fortification for many years. Few of the nutrients are mandatorily implemented, and many are implemented voluntarily by local industries.

The goal of the present review was to survey the severity of nutritional deficiencies in Israel, and to suggest ways to prevent and treat this problem. Our hypothesis is that, in view of the special characteristics of Israel, despite being a developed country, with massive immigration, poverty and low social conditions, a high rate of nutritional deficiencies exist.

The present review is also aimed to summarize the subject, as a step to promote food fortification in Israel.

\section{RESEARCH}

The extent and severity of nutritional deficiencies in Israel were reviewed through a selective and targeted Medline survey of previous reports and studies performed during the last 40 years.

The key words for the Medline search were combinations of the words: children, pediatrics, Israel, nutrients, nutrition, deficiency, fortification, as well as of specific nutrients such as iron, vitamins A, B, C, D, E, B12, Folic acid, calcium, phosphorus, magnesium, zinc and iodine.

\section{NUTRITIONAL DEFICIENCIES IN THE MODERN WORLD: CAUSES AND OUTCOME}

The food consumption habits of the children changed during the last few decades, and they now consume too much fat, especially saturated fats, and sweetened beverages. They do not eat enough fruits or vegetables and consequently do not consume enough fiber. Most schoolchildren of low socioeconomic families consume less milk, cheese, meet, vegetables and fruits. Only a fifth of children consume the recommended daily amount of fruits and vegetables ${ }^{[5-8]}$. The calcium and iron intake among children is also low. One of the main reasons for the pediatric pandemia of obesity is the consumption of large amounts of soft drinks rich in sugar, accompanied by a lack of physical activity. It is essential to address nutrient and activity deficiencies as these may lead to chron- ic long-term health problems, such as obesity, coronary heart disease, type 2 diabetes, stroke, cancer, and osteoporosis. It is well documented that overweight children are more likely to become obese adults ${ }^{[1-3,5]}$. The most common nutrient deficiencies among school children are: calcium, fiber, folate, iron, magnesium, potassium and vitamin $\mathrm{E}$. It has been reported that the 2 most common deficiencies seen in generally healthy children are iron and vitamin D deficiencies ${ }^{[3]}$. Classical nutrient deficiencies lead to stunting (energy, protein and zinc), rickets (vitamin D) and other bone abnormalities (copper, zinc, vitamin C) ${ }^{[7,8]}$. Iron deficiency anemia, as a public health problem, has been well recognized in recent years in developing countries and even in developed ones, and has received considerable attention by the World Health Organization $(\mathrm{WHO})^{[2,8]}$. Vitamin D deficiency and osteoporosis are common in northern climates, but even in sunny countries such as Israel, Australia and southern Europe. It is especially common among the elderly, veiled, dark skinned, and other at-risk population groups, who are also regularly warned to avoid sunlight to prevent skin cancers $^{\left[{ }^{17}-9,11\right]}$

The prevalence of endemic goiter and other iodine deficiencies has been reduced since the use of iodination of salt ${ }^{[8]}$. MacDonald ${ }^{[14]}$ has reported that zinc deficiency in animals is characterized by growth inhibition and decreased food intake. Liu et a ${ }^{[15]}$ indicated that malnutrition predisposes to neurocognitive deficits, which in turn predispose to persistent externalizing behavior problems throughout childhood and adolescence. Their findings suggest that reducing early malnutrition may help reduce later antisocial and aggressive behavior.

\section{NUTRITIONAL DEFICIENCIES IN ISRAEL}

In Israel, nutritional deficiencies have been documented throughout the last years in many reports.

\section{Deficiencies in special ethnic minorities}

In the Bedouin population ${ }^{[16-29]}$, short stature, iron deficiency, vitamin A deficiency (15\%-26\% of infants), B12 deficiency, and vitamin E deficiency have been reported. In Ethiopians living in Israel, there are several reports of vitamin $\mathrm{D}$ deficiency and rickets ${ }^{[30,31]}$.

\section{Regional deficiencies}

There were several reports on nutritional deficiencies in specific regions in Israel, including iron deficiency in children from central regions such as Hadera ${ }^{[32]}$; iron deficiency in Jewish children from a new immigrant town ${ }^{[33]}$; anemia in Jewish and Arab children from Akko ${ }^{[34]}$; iron deficiency anemia in infants from southern Israel ${ }^{[35]}$; and iron and folate deficiencies in children from a city in the North of Israel (Kyriat-Shmona) ${ }^{[36]}$.

\section{Special populations have demonstrated specific nutritional deficiencies}

In adolescents, several deficiencies were reported, includ- 
Table 1 Summary of the main nutritional deficiencies in the Israeli population

\begin{tabular}{lll}
\hline Israeli sub-population & \multicolumn{1}{c}{ Nutritional deficiency } & \multicolumn{1}{c}{ Ref. } \\
\hline Bedouins & $\begin{array}{l}\text { Iron, vitamin A, vitamin B12, } \\
\text { vitamin E }\end{array}$ & {$[16-29]$} \\
Ethiopians & Vitamin D & {$[30,31]$} \\
Specific regions & Iron, folic acid, vitamin B12 & {$[32,36,69]$} \\
Adolescents & Iron, vitamin D, calcium, & {$[9,38-40]$} \\
& phosphor, magnesium, zinc & \\
Toddlers & Vitamin D, Iron, Calcium & {$[41,42]$} \\
Overweight children & Iron, vitamin B12, folic acid, & {$[43-45]$} \\
& phosphorus, calcium, vitamin D & \\
Military recruits & Iron, magnesium & {$[46-48]$} \\
Infants & Iron & {$[32,49-53]$} \\
Vegetarians & Vitamin D, vitamin B12, vitamin & {$[54-57]$} \\
Pregnant women & B1, iron, zinc & \\
Helicobacter pylori gastritis & Iron & {$[58,59]$} \\
Celiac disease patients & Iron & {$[60]$} \\
Gaucher patients & Vitamin D & {$[10,61]$} \\
Anorexia nervosa patients & Vitamin B12 & {$[68]$} \\
\hline
\end{tabular}

ing iron deficiency (especially in athletes) ${ }^{[37]}$, and deficiencies in vitamin $\mathrm{D}^{[9,38,39]}$, calcium, phosphor, magnesium and zinc ${ }^{[40]}$. Toddlers and adolescents in Israel, as in other Western countries, are using "energy drinks", which can cause nutritional deficiencies such as vitamin D and iron $^{[41]}$. A study of children from central Israel ${ }^{[42]}$ revealed a lack of calcium in their food and decreased bone density. Children with overweight demonstrated iron deficiency $^{[43]}$ and vitamin B12 deficiency ${ }^{[44]}$. In bariatric surgery candidates, deficiencies in iron, folic acid, ferritin, $\mathrm{B} 12$, phosphor, calcium and vitamin D were reported ${ }^{[45]}$.

In military recruits and in soldiers, iron deficiency ${ }^{[46,47]}$, and low magnesium levels ${ }^{[48]}$ were noted.

A high percentage of the infant population in Israel has iron deficiency anemia ${ }^{[32,49-52]}$. It can badly affect their learning achievements and behavior ${ }^{[53]}$.

In the vegetarian population, there was a lack of calories and proteins, rickets, osteoporosis, B12 and B1 deficiencies, iron and zinc deficiencies, and increased risk of infections ${ }^{[54-57]}$. A high incidence of iron deficiency was noted in pregnant women ${ }^{[58,59]}$. Iron deficiency anemia was reported also in people with Helicobacter pylori (H. Pylori) gastritis ${ }^{[60]}$. Children with celiac disease had low bone mineral density. Their average serum vitamin D level was $25.6 \mathrm{ng} / \mathrm{L}$, suggestive of osteopenia ${ }^{[10,61]}$.

\section{Specific deficiencies}

Iron deficiency anemia has been extensively documented in Israel, especially in infants ${ }^{[8,33,35,49-52]}$, adolescents ${ }^{[47]}$, pregnant women ${ }^{[58]}$, adults and the elderly ${ }^{[8]}$.

Vitamin D deficiency is common in the Israeli population. In $2009,87 \%$ of the adult population and $52 \%$ of the pediatric population had low vitamin D levels ${ }^{[11,62-65]}$. Rickets in infants is attributable to inadequate vitamin D intake and decreased exposure to sunlight. It seems that vitamin D leading to osteoporosis is common in the elderly even in sunny countries such as Israel ${ }^{[63]}$. Vitamin D deficiency is also associated with autoimmune diseases ${ }^{[64]}$. Orthodox mothers after delivery had low levels of vita$\min \mathrm{D}^{[66]}$.

Vitamin B12 and folate deficiencies has been noted in Israeli children, especially as a result of low intake of vegetables $^{[44,67]} ; 22 \%$ of Ashkenazi Jews and $40 \%$ of Gaucher patients in Israel were reported to have B12 deficiency ${ }^{[68]}$. In Beer Sheva, a city in the south of Israel, 37\% of the population had B12 deficiency ${ }^{[69]}$. Recent reports by Kark et al ${ }^{[12]}$ have shown high homocysteine levels among Israelis, and despite vast reductions in mortality rates, the rates of coronary heart disease are still very high. Folic acid, as an antagonist to homocysteine, is increasingly accepted as a major preventive factor in coronary heart disease ${ }^{[13]}$.

Zinc deficiency was noted, among other nutrient deficiencies, in anorexia nervosa patients in Israel ${ }^{[70,71]}$. Zinc deficiency was also reported in children ${ }^{[72]}$, and in attention deficit hyperactivity disorder patients ${ }^{[73]}$. Table 1 summarizes the nutritional deficiencies in Israel described in our study.

In summary, Israeli populations have multiple nutritional deficiencies including iron, calcium, zinc, folic acid, and vitamins B12, C, D and E, spanning all age groups, several minorities, and specific regions. The most common nutritional deficiencies in the pediatric age group in Israel are iron and vitamin D. These deficiencies are mostly common in special populations, such as Bedouins, vegetarians, Ethiopians, obese children, pregnant women and their babies, gluten-sensitive populations, children with H. Pylori, children with behavioral problems and anorexia, diabetics, but deficiencies span the whole Israeli population.

\section{FOOD FORTIFICATION}

Fortification of commonly eaten foods with micronutrients offers a cost-effective solution that can reach large populations $^{[74]}$.

It is the responsibility of public health authorities to ensure that the general population, and especially those under in poverty are assured of an adequate basic daily intake of minerals and vitamins. This can only be achieved through appropriate vitamin and mineral enrichment of basic foods. Food fortification can reach many people who either do not or cannot comply with the individual approach of health education and healthy diet, due to its higher cost, or due to a lack of knowledge or access ${ }^{[75,76]}$. The addition of micronutrients to food for health reasons has been known for many years ${ }^{[8,77,78]}$.

Food fortification was adopted in the United States during the 1920s and the 1930s, by enriching flour in order to eliminate pellagra in the southern states. In 1942, a program to enrich flour with vitamins and iron was adopted by the United States government ${ }^{[7]}$. In the beginning it included enriching flour with vitamin B1 (thiamin) to prevent beriberi, niacin to prevent pellagra, riboflavin for efficient use of vitamin B6, and iron to prevent anemia. Later, it was decided to also add vitamin 
$\mathrm{D}$ and calcium, and it was expanded to enrich corn flour in 1943, pasta in 1946, and rice in 1958. The success of this program led to additional fortification of breakfast cereals with B-vitamins and iron in $1969^{[75]}$.

In Canada, food fortification has been mandatory since 1979 , including iodine in salt, iron and vitamin B complex in flour, and vitamin A and D in milk products. In 1998, folic acid was additionally added to flour, with positive effects in reduction of neural tube defects within 2 years ${ }^{[79]}$. Fortification of flour and grains with folate was adopted also in the United States in 1998, and was followed by a decline in the total prevalence of neural tube defects ${ }^{[80]}$.

In Europe, food fortification has encountered considerable opposition over the past 2 decades (especially in Scandinavian countries). Nevertheless, it has recently been put into practice, with most countries fortifying salt with iodine to prevent iodine deficiency ${ }^{[81]}$.

In 1996, the WHO has renewed its call for the universal iodization of salt, since iodine deficiency was considered the greatest cause of preventable brain damage and mental retardation worldwide ${ }^{[82]}$. In addition, the WHO also promotes fortification and supplementation for reduction of iron deficiency anemia, vitamin A deficiency and others, although referring usually to developing countries.

Regarding vitamin D deficiency, it has been widely recognized, not only with reference to infants and children, but also for other age groups, including adolescents and older age groups. In 2003, the American Academy of Pediatrics emphasized the importance of milk fortification with vitamin D supplementation throughout childhood and adolescence, with consideration of subclinical vitamin $\mathrm{D}$ deficiency in many population groups ${ }^{[83]}$.

Israel is working towards food fortification, but it is on a voluntary basis for some vitamins and minerals, while mandatory for others, such as fortification of salt, milk products and flour. Nevertheless, most salt sold to the Israeli population is still un-iodized ${ }^{[78]}$. As previously mentioned, although Israel is a sunny country, vitamin $\mathrm{D}$ deficiency is well recognized among the elderly ${ }^{[10,19,66]}$, partly related to the advice to avoid sunlight exposure for fear of skin cancer. This fact makes vitamin D fortification of milk products a necessity.

The successful experience of food fortification in many countries emphasizes the safety and efficacy of this approach. Food fortification is vital in prevention of chronic diseases, and its implementation will bring longterm economic savings in health costs and will contribute to the health and nutritional habits of the population. In addition to fortification of breakfast cereals and some milk products, the recommendations of health ministries should include fortification of basic foods with iodine, iron, folic acid, vitamin A, vitamin B complexes (including B12), and vitamin D, in order to prevent birth defects as well as chronic diseases. National school feeding programs can be one of the means for nutritional education and food fortification as well as a means of alleviating food insecurity among children.

The limitations of our study are embedded in the methodology of the literature search, since some publications could have been missed or were unavailable in Medline. There is also a possibility of publication bias since negative or non-significant studies tend not to be published.

In summary, in view of the wide nutritional deficiencies in Israel, we encourage local health, education and industrial ministries to expand efforts to study and document these deficiencies with a view to fortifying basic commonly used foods in order to combat the deficiencies and prevent their occurrence in the future.

\section{REFERENCES}

1 Lutter CK. Iron deficiency in young children in low-income countries and new approaches for its prevention. J Nutr 2008; 138: 2523-2528 [PMID: 19022983 DOI: 10.3945/jn.108.095406]

2 ACC/SCN. Fourth report on the world nutrition situation. Switzerland: United Nations ACC/SCN in collaboration with IFPRI, 2000

3 Suskind DL. Nutritional deficiencies during normal growth. Pediatr Clin North Am 2009; 56: 1035-1053 [PMID: 19931062 DOI: $10.1016 / j . p c l .2009 .07 .004]$

4 Prevention of neural tube defects: results of the Medical Research Council Vitamin Study. MRC Vitamin Study Research Group. Lancet 1991; 338: 131-137 [PMID: 1677062 DOI: 10.1016/0140-6736(91)90133-A]

5 Caballero B. Global patterns of child health: the role of nutrition. Ann Nutr Metab 2002; 46 Suppl 1: 3-7 [PMID: 12428075]

6 Bhaskaram P. Micronutrient malnutrition, infection, and immunity: an overview. Nutr Rev 2002; 60: S40-S45 [PMID: 12035857 DOI: 10.1301/00296640260130722]

7 Gat-Yablonski G, Yackobovitch-Gavan M, Phillip M. Nutrition and bone growth in pediatrics. Endocrinol Metab Clin North Am 2009; 38: 565-586 [PMID: 19717005 DOI: 10.1016/j. ecl.2009.07.001]

8 Tulchinsky TH. Vitamin enrichment of basic foods: the casefor-action in Israel. Isr J Med Sci 1993; 29: 58-61 [PMID: 8454455]

9 Ish Shalom S, Rozen GS, Lerner A. In: "Pediatric Nutrition", Eds. Reifen RM, Lerner A, Branski D, Heymans ASA. Osteoporosis: An Emerging Problem in Pediatrics. Karger: Basel, 1998: 110-121

10 Lerner A, Shapira Y, Agmon-Levin N, Pacht A, Ben-Ami Shor D, López HM, Sanchez-Castanon M, Shoenfeld Y. The clinical significance of $25 \mathrm{OH}-\mathrm{Vitamin} \mathrm{D}$ status in celiac disease. Clin Rev Allergy Immunol 2012; 42: 322-330 [PMID: 21210250 DOI: 10.1007/s12016-010-8237-8]

11 Oren Y, Shapira Y, Agmon-Levin N, Kivity S, Zafrir Y, Altman A, Lerner A, Shoenfeld Y. Vitamin D insufficiency in a sunny environment: a demographic and seasonal analysis. Isr Med Assoc J 2010; 12: 751-756 [PMID: 21348404]

12 Kark JD, Sinnreich R, Rosenberg IH, Jacques PF, Selhub J. Plasma homocysteine and parental myocardial infarction in young adults in Jerusalem. Circulation 2002; 105: 2725-2729 [PMID: 12057985 DOI: 10.1161/01.CIR.0000017360.99531.26]

13 Anderson JL, Jensen KR, Carlquist JF, Bair TL, Horne BD, Muhlestein JB. Effect of folic acid fortification of food on homocysteine-related mortality. Am J Med 2004; 116: 158-164 [PMID: 14749159 DOI: 10.1016/j.amjmed.2003.10.024]

14 MacDonald RS. The role of zinc in growth and cell proliferation. J Nutr 2000; 130: 1500S-1508S [PMID: 10801966]

15 Liu J, Raine A, Venables PH, Mednick SA. Malnutrition at age 3 years and externalizing behavior problems at ages 8, 11, and 17 years. Am J Psychiatry 2004; 161: 2005-2013 [PMID: 15514400 DOI: 10.1176/appi.ajp.161.11.2005] 
16 Forman MR, Guptill KS, Chang DN, Sarov B, Berendes HW, Naggan L, Hundt GL. Undernutrition among Bedouin Arab infants: the Bedouin Infant Feeding Study. Am J Clin Nutr 1990; 51: 343-349 [PMID: 2309641]

17 Costeff H, Breslaw Z. Rickets in southern Israel. Some epidemiologic observations. J Pediatr 1962; 61: 919-924 [PMID: 14023307 DOI: 10.1016/S0022-3476(62)80206-6]

18 Harlap S, Prywes R, Grover NB, Davies AM. Maternal, perinatal and infant health in Bedouin and Jews in southern Israel. Isr J Med Sci 1977; 13: 514-528 [PMID: 873768]

19 Groen JJ, Eshchar J, Ben-ishay D, Alkan WJ, Benassa BI. Osteomalacia among the bedouin of the negev desert; clinical and biochemical observations. Arch Intern Med 1965; 116: 195-204 [PMID: 14318477 DOI: 10.1001/archinte.1965.038700 20035010]

20 Levy A, Fraser D, Rosen SD, Dagan R, Deckelbaum RJ, Coles C, Naggan L. Anemia as a risk factor for infectious diseases in infants and toddlers: results from a prospective study. Eur J Epidemiol 2005; 20: 277-284 [PMID: 15921046 DOI: 10.1007/ s10654-004-6515-6]

21 Weisman Y. Vitamin D deficiency rickets and osteomalacia in Israel. Isr Med Assoc J 2003; 5: 289-290 [PMID: 14509137]

22 Berlyne GM, Ben-Ari J, Nord E, Shainkin R. Bedouin osteomalacia due to calcium deprivation caused by high phytic acid content of unleavened bread. Am J Clin Nutr 1973; 26: 910-911 [PMID: 4727748]

23 Sasson A, Etzion Z, Shany S, Berlyne GM, Yagil R. Growth and bone mineralisation as affected by dietary calcium, phytic acid and vitamin D. Comp Biochem Physiol A Comp Physiol 1982; 72: 43-48 [PMID: 6124364]

24 Shany S, Hirsh J, Berlyne GM. 25-Hydroxycholecalciferol levels in bedouins in the Negev. Am J Clin Nutr 1976; 29: 1104-1107 [PMID: 973599]

25 Shany S, Biale Y, Zuili I, Yankowitz N, Berry JL, Mawer EB. Feto-maternal relationships between vitamin D metabolites in Israeli Bedouins and Jews. Am J Clin Nutr 1984; 40: 1290-1294 [PMID: 6334437]

26 Biale Y, Shany S, Levi M, Shainkin-Kestenbaum R, Berlyne GM. 25 Hydroxycholecalciferol levels in Beduin women in labor and in cord blood of their infants. Am J Clin Nutr 1979; 32: 2380-2382 [PMID: 506960]

27 Coles CL, Levy A, Gorodischer R, Dagan R, Deckelbaum RJ, Blaner WS, Fraser D. Subclinical vitamin A deficiency in Israeli-Bedouin toddlers. Eur J Clin Nutr 2004; 58: 796-802 [PMID: 15116083 DOI: 10.1038/sj.ejcn.1601879]

28 Gorodischer R, Sarov B, Gazala E, Hershkovitz E, Edwardson S, Sklan D, Katz M. Differences in cord serum retinol concentrations by ethnic origin in the Negev (southern Israel). Early Hum Dev 1995; 42: 123-130 [PMID: 7588157 DOI: 10.1016/0378-3782(95)01644-I]

29 Masalha R, Rudoy I, Volkov I, Yusuf N, Wirguin I, Herishanu YO. Symptomatic dietary vitamin B(12) deficiency in a nonvegetarian population. Am J Med 2002; 112: 413-416 [PMID: 11904118 DOI: 10.1016/S0002-9343(02)01031-8]

30 Ginat-Israeli T, Dranitzki Z, Straus U. Nutritional rickets in infants immigrating to Israel from Ethiopia. Isr Med Assoc J 2003; 5: 291-292 [PMID: 14509138]

31 Fogelman Y, Rakover Y, Luboshitzky R. High prevalence of vitamin D deficiency among Ethiopian women immigrants to Israel: exacerbation during pregnancy and lactation. Isr J Med Sci 1995; 31: 221-224 [PMID: 7721559]

32 Lavon B, Tulchinsky TH, Preger M, Said R, Kaufman S. Iron deficiency anemia among Jewish and Arab infants at 6 and 12 months of age in Hadera, Israel. Isr J Med Sci 1985; 21: 107-112 [PMID: 3980188]

33 Yodfat Y. Iron deficiency anemia in children in a newimmigrant town in Israel. Isr J Med Sci 1967; 3: 890-893 [PMID: 5587580]

34 Shehab S, Nutenko K, Koren A, Ron M, Salahov E, Tulchinsky T. [Hemoglobin level among infants in Akko sub-dis- trict]. Harefuah 2001; 140: 1002-1005, 1120 [PMID: 11759370]

35 Bilenko N, Yehiel M, Inbar Y, Gazala E. The association between anemia in infants, and maternal knowledge and adherence to iron supplementation in southern Israel. Isr Med Assoc J 2007; 9: 521-524 [PMID: 17710783]

36 Levy S, Rachmilewitz M, Grossowicz N, Reshef Y, Izak G. Nutritional survey in an iron- and folate-deficient population. Am J Clin Nutr 1975; 28: 1454-1457 [PMID: 803008]

37 Constantini NW, Eliakim A, Zigel L, Yaaron M, Falk B. Iron status of highly active adolescents: evidence of depleted iron stores in gymnasts. Int J Sport Nutr Exerc Metab 2000; 10: 62-70 [PMID: 10939876]

38 Stoffman N, Gordon CM. Vitamin D and adolescents: what do we know? Curr Opin Pediatr 2009; 21: 465-471 [PMID: 19502985 DOI: 10.1097/MOP.0b013e32832da096]

39 Huh SY, Gordon CM. Vitamin D deficiency in children and adolescents: epidemiology, impact and treatment. Rev Endocr Metab Disord 2008; 9: 161-170 [PMID: 18175220 DOI: 10.1007/ s11154-007-9072-y]

40 Rozen GS, Rennert G, Rennert HS, Diab G, Daud D, Ish-Shalom S. Calcium intake and bone mass development among Israeli adolescent girls. J Am Coll Nutr 2001; 20: 219-224 [PMID: 11444417 DOI: 10.1080/07315724.2001.10719035]

41 Carvalho NF, Kenney RD, Carrington PH, Hall DE. Severe nutritional deficiencies in toddlers resulting from health food milk alternatives. Pediatrics 2001; 107: E46 [PMID: 11335767 DOI: 10.1542/peds.107.4.e46]

42 Prais D, Diamond G, Kattan A, Salzberg J, Inbar D. The effect of calcium intake and physical activity on bone quantitative ultrasound measurements in children: a pilot study. J Bone Miner Metab 2008; 26: 248-253 [PMID: 18470665 DOI: 10.1007/s00774-007-0814-4]

43 Pinhas-Hamiel O, Newfield RS, Koren I, Agmon A, Lilos P, Phillip M. Greater prevalence of iron deficiency in overweight and obese children and adolescents. Int J Obes Relat Metab Disord 2003; 27: 416-418 [PMID: 12629572 DOI: 10.1038/sj.ijo.0802224]

44 Pinhas-Hamiel O, Doron-Panush N, Reichman B, NitzanKaluski D, Shalitin S, Geva-Lerner L. Obese children and adolescents: a risk group for low vitamin B12 concentration. Arch Pediatr Adolesc Med 2006; 160: 933-936 [PMID: 16953016 DOI: 10.1001/archpedi.160.9.933]

45 Schweiger C, Weiss R, Berry E, Keidar A. Nutritional deficiencies in bariatric surgery candidates. Obes Surg 2010; 20: 193-197 [PMID: 19876694 DOI: 10.1007/s11695-009-0008-3]

46 Israeli E, Merkel D, Constantini N, Yanovich R, Evans RK, Shahar D, Moran DS. Iron deficiency and the role of nutrition among female military recruits. Med Sci Sports Exerc 2008; 40: S685-S690 [PMID: 18849865 DOI: 10.1249/ MSS.0b013e31818946ae]

47 Rachmilewitz EA, Blank D, Rohash Z, Polliack A. [Thalassemia minor and iron deficiency anemia among Israeli soldiers]. Harefuah 1986; 110: 437-441 [PMID: 3758857]

48 Dolev E, Burstein R, Wishnitzer R, Lubin F, Chetriet A, Shefi $\mathrm{M}$, Deuster PA. Longitudinal study of magnesium status of Israeli military recruits. Magnes Trace Elem 1992; 10: 420-426 [PMID: 1669024]

49 Meyerovitch J, Sherf M, Antebi F, Barhoum-Noufi M, Horev $\mathrm{Z}$, Jaber L, Weiss D, Koren A. The incidence of anemia in an Israeli population: a population analysis for anemia in 34,512 Israeli infants aged 9 to 18 months. Pediatrics 2006; 118: e1055-e1060 [PMID: 16940163 DOI: 10.1542/peds.2006-0024]

50 Palti H, Adler B, Wolf N. An epidemiological study of haemoglobin levels in infancy in Jerusalem. The effect of social factors and the relation to physical growth. Acta Paediatr Scand 1977; 66: 513-517 [PMID: 899769 DOI: 10.1111/j.1651-2227.1977. tb07936.x]

51 Tulchinsky TH, Tamirab D, Sebanab AJ. Changing pattern of anemia among Jerusalem infants between 1977 and 1987. Early Child Dev Care 1991; 66: 75-83 [DOI: 10.1080/030044391 
0660107]

52 Lev B. Prevention of micronutrient deficiency conditions: the Israeli approach. Public Health Rev 2000; 28: 13-21 [PMID: 11411266]

53 Palti H, Meijer A, Adler B. Learning achievement and behavior at school of anemic and non-anemic infants. Early Hum Dev 1985; 10: 217-223 [PMID: 3987574 DOI: 10.1016/037 8-3782(85)90052-0]

54 Zmora E, Gorodischer R, Bar-Ziv J. Multiple nutritional deficiencies in infants from a strict vegetarian community. Am J Dis Child 1979; 133: 141-144 [PMID: 105630]

55 Abu-Kishk I, Rachmiel M, Hoffmann C, Lahat E, Eshel G. Infantile encephalopathy due to vitamin deficiency in industrial countries. Childs Nerv Syst 2009; 25: 1477-1480 [PMID: 19585126 DOI: 10.1007/s00381-009-0942-3]

56 Ashkenazi S, Weitz R, Varsano I, Mimouni M. Vitamin B12 deficiency due to a strictly vegetarian diet in adolescence. Clin Pediatr (Phila) 1987; 26: 662-663 [PMID: 3677536 DOI: 10.1177/000992288702601211]

57 Shinwell ED, Gorodischer R. Totally vegetarian diets and infant nutrition. Pediatrics 1982; 70: 582-586 [PMID: 6812012]

58 Palgi A. Ethnic differences in hemoglobin distribution of Asian and European Jewish women in Israel, both pregnant and nonpregnant. Am J Public Health 1981; 71: 847-851 [PMID: 7258448 DOI: 10.2105/AJPH.71.8.847]

59 Edet EE. Prevalence of anaemia among pregnant women in a Jewish community in Jerusalem according to selected sociodemographic characteristics. Public Health 1990; 104: 457-463 [PMID: 2274649 DOI: 10.1016/S0033-3506(05)80088-5]

60 Hershko C, Hoffbrand AV, Keret D, Souroujon M, Maschler I, Monselise Y, Lahad A. Role of autoimmune gastritis, Helicobacter pylori and celiac disease in refractory or unexplained iron deficiency anemia. Haematologica 2005; 90: 585-595 [PMID: 15921373]

61 Hartman C, Hino B, Lerner A, Eshach-Adiv O, Berkowitz D, Shaoul R, Pacht A, Rozenthal E, Tamir A, Shamaly H, Shamir R. Bone quantitative ultrasound and bone mineral density in children with celiac disease. J Pediatr Gastroenterol Nutr 2004; 39: 504-510 [PMID: 15572890 DOI: 10.1097/000051 76-200411000-00011]

62 Nehama H, Wientroub S, Eisenberg Z, Birger A, Milbauer B, Weisman $Y$. Seasonal variation in paired maternal-newborn serum 25-hydroxyvitamin D and 24,25-dihydroxyvitamin D concentrations in Israel. Isr J Med Sci 1987; 23: 274-277 [PMID: 3497905]

63 Meller Y, Kestenbaum RS, Galinsky D, Shany S. Seasonal variation in serum levels of vitamin D metabolites and parathormone in geriatric patients with fractures in Southern Israel. Isr J Med Sci 1986; 22: 8-11 [PMID: 3485617]

64 Shoenfeld N, Amital H, Shoenfeld Y. The effect of melanism and vitamin $\mathrm{D}$ synthesis on the incidence of autoimmune disease. Nat Clin Pract Rheumatol 2009; 5: 99-105 [PMID: 19182816 DOI: $10.1038 /$ ncprheum0989]

65 Weisman Y. Osteoporosis and vitamin D deficiency in Israel. Public Health Rev 2000; 28: 59-65 [PMID: 11411278]

66 Mukamel MN, Weisman Y, Somech R, Eisenberg Z, Landman J, Shapira I, Spirer Z, Jurgenson U. Vitamin D deficiency and insufficiency in Orthodox and non-Orthodox Jewish mothers in Israel. Isr Med Assoc J 2001; 3: 419-421 [PMID: 11433634]
67 Allen LH. Causes of vitamin B12 and folate deficiency. Food Nutr Bull 2008; 29: S20-S34; discussion S35-S37 [PMID: 18709879]

68 Gielchinsky Y, Elstein D, Green R, Miller JW, Elstein Y, Algur N, Lahad A, Shinar E, Abrahamov A, Zimran A. High prevalence of low serum vitamin B12 in a multi-ethnic Israeli population. Br J Haematol 2001; 115: 707-709 [PMID: 11736958 DOI: 10.1046/j.1365-2141.2001.03156.x]

69 Volkov I, Rudoy I, Machagna M, Glezer I, Ganel U, Orenshtein A, Press Y. Modern society and prospects of low vitamin B12 intake. Ann Nutr Metab 2007; 51: 468-470 [PMID: 18025821 DOI: $10.1159 / 000111168]$

70 Aloufy A, Latzer Y. [Diet or health--the linkage between vegetarianism and anorexia nervosa]. Harefuah 2006; 145: 526-531, 549 [PMID: 16900745]

71 Tannhauser PP. Anorexia nervosa: a multifactorial disease of nutritional origin? Int J Adolesc Med Health 2002; 14: 185-191 [PMID: 12467193 DOI: 10.1515/IJAMH.2002.14.3.185]

72 Naveh Y. [Zinc deficiency in children]. Harefuah 1995; 128: 728-732 [PMID: 7557676]

73 Toren P, Eldar S, Sela BA, Wolmer L, Weitz R, Inbar D, Koren S, Reiss A, Weizman R, Laor N. Zinc deficiency in attention-deficit hyperactivity disorder. Biol Psychiatry 1996; 40: 1308-1310 [PMID: 8959299 DOI: 10.1016/S0006-3223(96)0 0310-1]

74 Tulchinsky TH, Kaluski DN, Berry EM. Food fortification and risk group supplementation are vital parts of a comprehensive nutrition policy for prevention of chronic diseases. Eur J Public Health 2004; 14: 226-228 [PMID: 15369023 DOI: 10.1093/eurpub/14.3.226]

75 Centers for Disease Control and Prevention (CDC). Safer and healthier foods. MMWR Morb Mortal Wkly Rep 1999; 48: 905-913 [PMID: 12432905]

76 Park YK, Sempos CT, Barton CN, Vanderveen JE, Yetley EA. Effectiveness of food fortification in the United States: the case of pellagra. Am J Public Health 2000; 90: 727-738 [PMID: 10800421]

77 Kaluski DN, Tulchinsky TH, Haviv A, Averbuch Y, Rachmiel S, Berry EM, Leventhal A. Addition of essential micronutrients to foods--implication for public health policy in Israel. Isr Med Assoc J 2003; 5: 277-280 [PMID: 14509134]

78 Israeli A, Shemer J. It is time to fortify basic foods in Israel according to the Canadian model. Isr Med Assoc J 2004; 6: 323-325 [PMID: 15214455]

79 Ray JG, Meier C, Vermeulen MJ, Boss S, Wyatt PR, Cole DE. Association of neural tube defects and folic acid food fortification in Canada. Lancet 2002; 360: 2047-2048 [PMID: 12504403 DOI: 10.1016/S0140-6736(02)11994-5]

80 Honein MA, Paulozzi LJ, Mathews TJ, Erickson JD, Wong LY. Impact of folic acid fortification of the US food supply on the occurrence of neural tube defects. JAMA 2001; 285: 2981-2986 [PMID: 11410096 DOI: 10.1001/jama.285.23.2981]

81 Vitti P, Delange F, Pinchera A, Zimmermann M, Dunn JT. Europe is iodine deficient. Lancet 2003; 361: 1226 [PMID: 12686067]

82 World Health Organization. Iodine Deficiency disorders. Fact Sheet No. 121. Geneva: WHO, 1990

83 Gartner LM, Greer FR. Prevention of rickets and vitamin D deficiency: new guidelines for vitamin D intake. Pediatrics 2003; 111: 908-910 [PMID: 12671133 DOI: 10.1542/peds.111.4.908]

P- Reviewers: Koch TR, Ramos S S- Editor: Gou SX L- Editor: Cant MR E- Editor: Liu SQ 


\section{DS \\ Baishideng ${ }^{\circledR}$}

Published by Baishideng Publishing Group Inc

8226 Regency Drive, Pleasanton, CA 94588, USA

Telephone: +1-925-223-8242

Fax: +1-925-223-8243

E-mail: bpgoffice@wignet.com

Help desk: http://www.wjgnet.com/esps/helpdesk.aspx

http://www.wignet.com

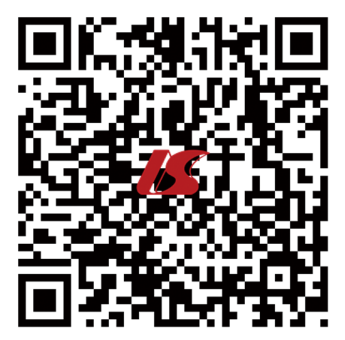

